\title{
Em busca por novos rumos na formação de professores
}

\section{Searching for new directions in teacher's education}

C. M. Teixeira, J. Vasconcelos-Raposo,

EDITORIAL | EDITORIAL

Desde o tempo de Platão que se constata a importância de brincar como forma de fomentar a educação e o desenvolvimento. Porém, as formas de brincar têm vindo a modificar-se ao longo do tempo, sendo que, actualmente, os jogos ao ar livre foram substituídos por brinquedos com características eletrónicas.

Os ensinamentos de Piaget e de Vygostsky, tornarem claro que o brincar é uma forma primária para as crianças interagirem com o meio ambiente bio-psico-socio-cultural, e dessa maneira construirem conhecimentos sobre o mundo, que é reforçado com as interacções que mantêm com as outras pessoas. Desta forma o brincar deverá ser entendido como o elemento privilegiado para a aprendizagem e desenvolvimento físico, cognitivo, social e emocional. Neste sentido, o jogo transforma-se numa necessidade essencial para as crianças crescerem e se desenvolverem.

A educação é primordial em todos os direitos humanos. A educação escolar, por sua vez, pretende construir uma sociedade criativa, bem informada e capaz digitalmente, com conhecimentos e capacidades flexíveis. No entanto, importa esclarecer que tudo isto não passa de mera retórica ideológica, caso não se tenham por base as realidades objectivas a que esses humanos são expostos no seu dia-a-dia e que, no presente, acontece com o que observam e sabem a um nível global.

Neste sentido, os jogos como estratégias de aprendizagem activa, são agentes estimuladores para a interação do aluno com os outros e com os elementos necessários para o desenvolvimento das suas capacidades, e os quais têm um design definido e são capazes de criar um ambiente de aprendizagem capaz de proporcionar conhecimentos através da prática. O século XX caracterizou-se pelos avanços tecnológicos que provocaram mudanças na sociedade, a nível global, de tal modo que se modificaram as formas como realizamos tarefas assim como pensamos o mundo em que nos inserimos. As novas tecnologias são utilizadas em diferentes contextos e o avanço destas contribuiu para o progresso de múltiplas áreas como, por exemplo, as da produção industrial, ciência, educação e saúde. Actualmente, vivemos num mundo digital que se impõe desde cedo na nossa vida, e no qual é cada vez mais essencial ser alfabetizado em tecnologia, que transmite inúmeras notícias e informações, e apoia as necessidades diárias.

O crescente uso da tecnologia na sociedade, em combinação com a atenção direccionada às questões de aprendizagem, exige que se façam alterações nos sistemas de ensino no sentido de mudarem para práticas de ensino mais adequadas aos tempos em que os jovens vivem. A tecnologia possibilita aos alunos 
construirem novos conhecimentos, incentiva e aumenta a eficácia e a eficiência dos processos de aprendizagem, e fornece aos professores novos recursos e materiais de ensino. As novas tecnologias, aplicadas ao ensino, oferecem novas possibilidades através das várias opções de ferramentas de aprendizagem em alternativa aos métodos pedagógicos mais convencionais.

A literatura da especialidade tem evidenciado que o uso da tecnologia resulta da sua facilidade de uso, através da atracção que exerce sobre os mais jovens, graças à sua utilidade, auto-eficácia, assim como do sentimento de satisfação elicitado entre os utilizadores mais jovens. Além disso, estas caracterizam-se, essencialmente por serem móveis, de grande flexibilidade quanto ao uso, facilidade de acesso. Exactamente por estas razões elas apresentam-se como valiosas e quase como uma necessidade imprescindível do quotidiano.

Os multimédia a que os jovens têm acesso têm mostrado poder ter um papel importante não só no desempenho da aprendizagem, bem como na satisfação, nas realizações, na análise e avaliação, na motivação, e na atenção dos jovens.

Mais recentemente há sinais de algumas tentativas de integração de se introduzir na formação dos professores algum tipo de desenvolvimento de competências nos domínios das Tecnologias de Informação e Comunicação (TIC). Na realidade tem procurado integrar essas ferramentas já a partir do jardim de infância, prolongando-se até ao final do ensino secundário.

Várias questões se levantam, por um lado exige-se a redefinição das habilidades profissionais do professor, de quem se espera ter competências de TIC, de forma a melhorar as experiências de aprendizagem do aluno. Por outro lado, as instituições de ensino não são minimamente financiadas para adquirir e para se manterem actualizadas quanto aos equipamentos com que os jovens convivem. e eficientemente utilizam diariamente. Mais ainda, professores e formadores são resistentes à ideia de terem de adquirir novas competências para as poderem reproduzir enquanto formadores de novas gerações de profissionais. Assim, ficam reunidas as condições para que na tecnologia se vejam males que nunca foram cientificamente comprovados.

$\mathrm{Na}$ década passada, foram desenvolvidos vários jogos educativos para ambientes escolares de nível primário, secundário e até universitário, com variados conteúdos temáticos. Utilizados como uma ferramenta para melhorar a aprendizagem e o ensino e que têm sido cada vez mais utilizados por crianças, os jogos educativos contribuem para o seu desenvolvimento ao nível sensório-motor, emocional e verbal.

Face ao exposto, parece-nos evidente a necessidade de promover, com alguma urgência novas áreas de formação de professores. No Laboratório MASSIVE VR Lab. (Multimodal Acknowleageable Multisensory Immersive Virtual Environments) actualmente decorrem estudos que visam desenvolver ferramentas com o objectivo da sua integração nas actividades de ensino. Esta equipa de pesquisadores, conscientes do modo como a instrução de ensino é actualmente levada a cabo, procura desenvolver linhas de pesquisa que conduzam ao aprofundamento do conhecimento vocacionado para a integração de novas metodologias de ensino e que tenham como instrumentos de intervenção equipamento que se apresentem atraentes e que possibilitem desenvolver nos alunos níveis mais elevados de motivação intrínseca. Para definir esta nova estratégia de ensino temos recorrido ao termo "Educação Imersiva" (Immersive Education). O uso das tecnologias é uma das estratégias que melhor se adequa para promover a tão desejada melhoria na aprendizagem e, eventualmente, na redução do abandono escolar. De acordo com Eyikara e Baykara, num trabalho publicado em 2018 com o título Effect of simulation on the ability of 
first year nursing students to learn vital signs, no Journal Nurse Education Today, aprendemos 10\% do que lemos, $20 \%$ do que ouvimos, $30 \%$ do que vemos e $90 \%$ do que ouvimos, tocamos e contamos. Neste contexto, parece-nos que o desenvolvimento de um ensino alicerçado em métodos imersivos de aprendizagem, vai ao encontro e inova os ambicionados avanços na tecnologia e para a promoção da aprendizagem através da experiência.

Influenciadas pela pesquisa e pelo desenvolvimento tecnológico, as tecnologias educativas, as quais no decorrer do tempo têm sido alvo de rápida expansão, dirigem a sua atenção no que respeita a capacitar e a envolver os alunos na educação. No entanto, segundo vários estudos, os educadores, os pesquisadores e os designers envolvidos nas tecnologias educativas, nem sempre estão devidamente treinados para garantir a produção de aplicativos construídos com bases teóricas sólidas e com padrões de alta qualidade para que estas contribuam, eficientemente, para o desenvolvimento dos alunos desde que são crianças.

$\mathrm{Na}$ sua concepção, este grupo de pesquisadores opta por utilizar o termo jogoficação para fazer referência ao conhecido termo inglês gamification. A literatura tem referido termos alternativos ao conceito de jogoficação, como é o caso do termo "jogos sérios", que é amplamente utilizado e o qual surgiu através de Clark Abt desenhador de vários jogos com um propósito educativo já no ano de 1960. A jogoficação é definida e caracterizada pelo uso e implementação de elementos lúdicos, mais especificamente, videolúdicos. Nos dias que correm, e em especial na educação, a jogoficação desem- penha um papel importante nos métodos e técnicas de aprendizagem, bem como no sucesso global do processo da mesma. Por sua vez, os jogos sérios definem-se como ferramentas de aprendizagem inovadoras e preponderantes cujo objetivo primordial é a integração da educação. No entanto, a literatura não é consensual relativamente ao uso dos termos "jogoficação" e "jogos sérios", pelo que alguns autores usam ambos como de igual natureza, enquanto outros referem que, apesar de semelhantes em alguns aspectos, se definem de forma diferente.

Num período em que as Instituições de Ensino Superior se deparam com dificuldades em recrutar alunos para os cursos em ensino e, concomitantemente, o sistema de ensino se depara com níveis elevados de abandono escolar e um crescente desinteresse por parte dos alunos, importa procurar alternativas para o ensino que as escolas oferecem hoje. É errado continuar a culpar os professores ou a artificialmente encontrar estratagemas que componham os dados estatísticos para que desse modo se faça crer que o se passa a nível dos resultados no ensino está a melhorar. É urgente encontrar formas de revalorizar a docência de modo a que os professores se sintam motivados e empenhados nos processos de inovação. Mais, importa mudar a forma como as Instituições de Ensino Superior são olhadas pelo poder político. Na prática, sempre que o poder político decide não proporcionar as condições/ recursos necessários para levar projectos de experimentação, estão a transformar os estabelecimentos em meros reprodutores de um saber estagnado no tempo. 